\section{Modern microbiology}

\section{Sydney Selwyn}

The Development of Microbiology. By Patrick Collard. Pp. $212+\mathrm{xx}$ photos. (Cambridge University: Cambridge, London and New York, November 1976.) £6.50.

THERE is probably no field of science or medicine which has a more fascinating and exciting history than microbiology. Paul de Kruif's classic, if over-romanticised, epic The Microbe Hunters has undoubtedly stimulated many young people to enter the medical and related professions during the 50 years since it was first published. The same source provided initial inspiration for the recent British television (BBC2) series Microbes and Men. The enthusiastic reception which greeted these dramatised sequences showed that the history of medical microbiology maintains a very wide appeal.

Paradoxically, however, this enthralling subject has received relatively little serious historical study. William Bulloch's History of Bacteriology stands alone as a detailed but idiosyncratic work. First published in 1938 it is now, sadly, unavailable. A briefer account by W. W. Ford, written in 1939, was followed more recently by W. D. Foster's general history. This contains a good survey of important French and German achievements of the nineteenth century but it neglects the earlier (and most recent) periods, and much of the less familiar British work. A very welcome event, therefore, is the publication of a new historical survey by Professor Collard of the Manchester Medical School. It arose from lectures to postgraduate students of medical microbiology and is admirably suited for such an audience. The cognoscenti, too, will find many delights but these will inevitably be tempered by disappointments especially in relation to the 'archeological' period before Pasteur.

The book is divided in a very practical way into thirteen main chapters which consider in turn the development of such aspects as microscopy, microbial cultivation, chemotherapy, genetics and serology. The author has wisely resisted the temptation to deal chronologically with the entire subject en masse. At the outset he delineates four eras through which microbiology has passed: speculation, from $5000 \mathrm{BC}$ to 1675 ; observation, from 1675 to the mid-nineteenth century; cultivation, to the beginning of the twentieth century; and the era of physiological study, persisting to the present day.

Although this view has the merit of simplicity, it presents a static picture of a dynamic subject. In particular, it ignores the fact that the volume and quantity of speculative writing actually continued to rise steadily after 1675. The later landmarks include Benjamin Marten's book on consumption of 1720 and Richard Bradley's treatise on the plague of the following year, but hundreds of others could be cited, culminating, during the midnineteenth century, in the writings of Jacob Henle on infection in general, William Budd on typhoid and John Snow on cholera.

Perhaps surprisingly, the greater part of this work was British-as was i! remarkable amount of more practical investigation. Microscopy begins logically with the elegant treatises on lenses by Roger Bacon and other Oxford philosophers of the thirteenth century, proceeding through the work of such forgotten figures as Leonard Digges, the elder, in the mid-sixteenth century.

The first practical microbiologist, however, was probably Thomas Moffett. This English physician, who is likely to have been the father of the celebrated "little Miss Muffet", not only described the infective cycle of silkworm disease, but also in 1589 provided a practical basis for a germ theory of disease with his study of the biology, pathology and treatment of scabies. Although Moffett is the undoubted founder of parasitology-and conceptually, of medical microbiology -he is totally neglected by the historians of these subjects. So also is one of the greatest theoreticians of all time, Francis Bacon, whose writings contain the roots of all that was to follow in microbiology. His assertion that an understanding of the processes underlying fermentation and putrefaction would be the key to the mysteries of disease and other "operations of nature" forms the basis for the later researches of Boyle, Willis, Pringle and their successors. Similarly, his perceptive remarks on the potential value of the new microscope lead directly to the work of that remarkable group of pioneer microscopists of the mid-seventeenth century-Mundy, Charleton, Power, Grew and Hooke. Only the latter has received any attention by historians of microbiology, and Professor Collard gives him merely passing mention.

Van Leeuwenhoek receives a more adequate amount of space, but some misconceptions need to be dispelled. $\mathrm{He}$ did not arise deus ex machina but his single-lens microscopes are perfect replicas of the type fully described ten years earlier by Robert Hooke, who also provided the idea of modified darkground illumination which probably determined van Leeuwenhoek's later successes. The Dutch draper was, moreover, incapable of producing the drawings contained in his famous letters to the Royal Society. Clifford Dobell, his reverential biographer, describes the mediocre quality of the work done for van Leeuwenhoek by his draughtsmen. So much so, that Professor Collard identifies "streptococci" from a sketch intended to portray, with a series of dots, the track of a mobile bacillus.

There are few such problems of interpretation in the modern period, although the story of Fleming's rediscovery of penicillin needs overhauling following Ronald Hare's revelations. Also Domagk's prontosil red was virtually inactive in vitro and was relatively ineffective against pneumococci in vivo. These and other minor errors should not be allowed to dissipate our genuine gratitude to the author. He has written the best available account of the development of modern microbiology.

Sydney Selwyn is a Reader in Medical Microbiology at Westminster Medical School, London, UK.

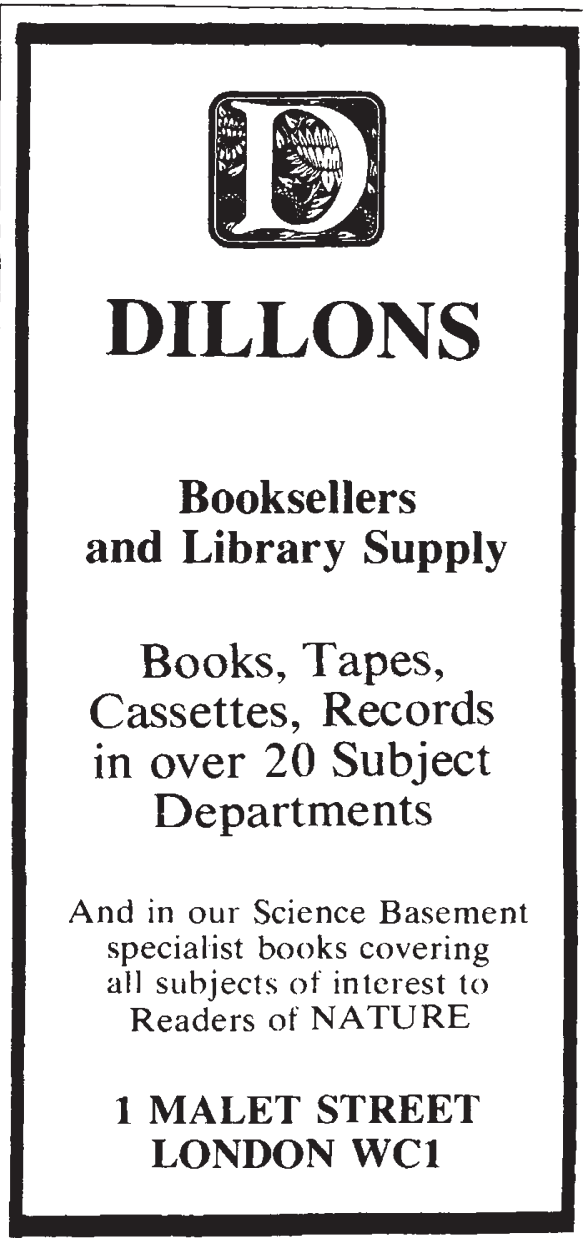

